\title{
Ocena potencjału terapeutycznego Temsirolimusu w zaawansowanym stadium renal cell carcinoma
}

\section{Evaluation of the therapeutic potential of Temsirolimus in advanced stage of renal cell carcinoma}

\author{
Wiktoria Maria Suchorska1,2, Mikołaj Nowak \\ ${ }^{1}$ Pracownia Radiobiologii, Zakład Fizyki Medycznej, Wielkopolskie Centrum Onkologii, ul. Garbary 15, 61-866 Poznań, Polska \\ ${ }^{2}$ Katedra i Zaktad Elektroradiologii, Uniwersytet Medyczny w Poznaniu, ul. Garbary 15, 61-866 Poznań, Polska
}

\section{Streszczenie}

Według najnowszych doniesień epidemiologicznych, jasnokomórkowy rak nerki (RCC) stanowi 3\% wszystkich nowotworów u dorosłych i wartość ta stale rośnie (w 2004 1,9\%). Patogeneza RCC jest ściśle związana z nadekspresją mTOR (mammalian Target of Rapamycin). Temsirolimus (TORISEL ${ }^{\mathrm{TM}}, C C I-779$, Wyeth Pharmaceuticals, Philadelphia, PA, USA) jest estrem Sirolimusu (Rapamycyny), którego potencjał terapeutyczny związany jest z inhibicją szlaku mTOR. Celem ogólnym pracy była ocena efektywności terapii Temsirolimusem myszy z ortotopowym jasnokomórkowym rakiem nerki. Wyniki doświadczenia wskazują na wydłużenie średniego czasu przeżycia (OS) zwierząt w grupie przyjmującej lek od momentu zidentyfikowania przerzutu ogniska nowotworowego w płucu zwierzęcia („CCI9met”) o około 7 dni w stosunku do dwóch pozostałych grup doświadczalnych: poddanej terapii Temsirolimusem 24 godziny po implantacji komórek nowotworowych („CCI9”) oraz myszy grupy kontrolnej („bez leczenia”).

\begin{abstract}
According to the latest epidemiological reports, clear cell renal cell carcinoma (RCC) represents $3 \%$ of all cancers in adults, and this value is constantly increasing (in 2004, 1.9\%). The pathogenesis of RCC is closely associated with overexpression of mTOR (mammalian Target of Rapamycin). Temsirolimus (TORISEL ${ }^{\mathrm{TM}}$, CCI-779, Wyeth Pharmaceuticals, Philadelphia, PA, USA) is an ester of sirolimus (rapamycin) whose therapeutic potential is linked to the inhibition of the mTOR pathway. The aim of this study was to evaluate the effectiveness of therapy with temsirolimus in mouse orthotopic model of clear cell renal carcinoma. The experiment results indicate an increase in overall survival (OS) of the animals in the group receiving the drug after the identification of metastasis of primary tumor in the lung („CCI9met”) by about seven days as compared to the other two treatment groups: the one treated with temsirolimus 24 hours after the tumor implantation („CCI9”) and control mice („untreated”).
\end{abstract}

Adres do korespondencji

dr n. med. Wiktoria Maria Suchorska

Kierownik Pracowni Radiobiologii

Wielkopolskie Centrum Onkologii,ul. Garbary 15, 61-866 Poznań, Polska

Telefon: +48618850477

e-mail: wiktoria.suchorska@wco.pl 
Stowa kluczowe: renal cell carcinoma; mTOR; temisirolimus; mysi ortotopowy model raka nerki

Key words: renal cell carcinoma; mTOR; temisirolimus; mouse orthotopic model

\section{Wstęp}

Pojęcie rak komórkowy nerki (RCC - Renal Cell Carcinoma) jest stosowane w odniesieniu do całej grupy nowotworów wywodzących się z nabłonka kanalików nerkowych. RCC stanowi 90\% guzów i jest najczęstszą formą nowotworów tego narządu. Jasnokomórkowy rak nerki (clear cell $R C C$ ), definiowany także jako konwencjonalny rak nerki (conventional renal cell carcinoma) rozwija się z komórek nabłonkowych kanalików proksymalnych i jest najczęściej diagnozowanym nowotworem komórkowym nerki (80\% RCC) [1].

Według najnowszych doniesień epidemiologicznych, RCC stanowi 3\% wszystkich nowotworów u dorosłych i wartość ta stale rośnie (w 2004 1,9\%). Spośród wszystkich nowotworów złośliwych nerki wykazuje najwyższy wskaźnik śmiertelności (40\% chorych umiera z powodu progresji choroby). U 1/3 chorych diagnozuje się przerzuty nowotworu do narządów odległych, u blisko 40\% wyleczonych i 20-30\% chorych po radykalnej nefrektomii obserwuje się nawrót choroby [2]. Prognoza zachorowalności wykazuje tendencję wzrostową [3].

Patogeneza RCC jest ściśle związana z nadekspresją mTOR (mammalian Target of Rapamycin) [4]. Serynowo-treoninowa kinaza białkowa mTOR jest naczelnym regulatorem cyklu komórkowego. Wykazuje wysoki plejotropizm funkcjonalny: mobilizuje komórki do podziałów mitotycznych, promuje neoangigenezę, wzmaga translację białek kluczowych dla biogenezy rybosomów, bierze udział w transporcie błonowym oraz hamuje apoptozę i autofagię [5]. Dowiedziono, że na skutek mutacji w obrębie genów kluczowych dla transformacji komórki w komórkę nowotworową (receptorów dla mitogenów, onkogenów czy genów supresorowych) dochodzi do nadmiernej aktywacji mTOR [6] również w RCC [7].

Temsirolimus (TORISEL ${ }^{\mathrm{TM}}$, CCI-779, Wyeth Pharmaceuticals, Philadelphia, PA, USA), jest estrem Sirolimusu (Rapamycyny), którego potencjał terapeutyczny związany jest z inhibicją szlaku mTOR. Sam Temsirolimus nie jest prolekiem, gdyż zarówno jego główny metabolit Sirolimus (Rapamycyna), jak i niezmetabolizowany Temsirolimus, wykazują hamujący wpływ na aktywność mTOR [8]. Temsirolimus wiąże się z wewnątrzkomórkową izomerazą prolinową FKBP12. Powstały kompleks jest kofaktorem łączącym się z domeną FRB położoną w centralnej części kompleksu mTOR i blokującym jego aktywność kinazową. Nieaktywny kompleks mTOR nie jest w stanie ufosforylować rybosomalnej S6K1 kinazy i eukariotycznego czynnika transkrypcyjnego E4BP1. W wyniku tego procesu dochodzi do zatrzymania komórki w fazie G1 na skutek zablokowania translacji mRNA dla cykliny D1 i dekarboksylazy ornitynowej [9]. Ponadto hamowanie szlaku mTOR doprowadza do obniżenia ekspresji HIF (Hypoxia Inducible Factor) i istotnie wpływa na ograniczenie angiogenezy w obrębie guza. Jest to szczególnie ważne w RCC, gdyż na skutek powszechnej w tym typie nowotworu mutacji w obrębie genu VHL (Von Hippel-Lindau gene), dochodzi do podwyższenia poziomu czynnika transkrypcyjnego HIF-1a poprzez zahamowanie jego degradacji [10-12]. Temsirolimus powodując obniżenie ekspresji HIF, hamuje angiogenezę poprzez obniżanie syntezy VEGFR (Vascular Endothelial Growth Factor Receptor) [13]. Wykazano także zdolność do indukowania apoptozy niezależnie od białka p53, na drodze aktywacji odpowiedzi komórki na czynniki stresowe poprzez ASK1 (Apoptosis Signal regulating Kinase1) [14]. Badania Wimmer i wsp. dowiodły, że podanie Temsirolimusu prowadzi do zahamowania migracji komórek nowotworowych, zarówno w hodowli komórkowej raka żołądka, jak i w przypadku wzrostu podskórnego in vivo [15]. Na podstawie wielu doświadczeń przedklinicznych i klinicznych stwierdzono, że inhibicja szlaku mTOR przez Rapamycynę i rapalogi odgrywa naczelną rolę $\mathrm{w}$ redukcji formowania guzów nowotworowych de novo [15].

FDA (Food and Drug Administration) zatwierdziło Temsirolimus jako lek stosowany z wyboru w zaawansowanym raku nerki (USA, maj 2006; EU, październik 2006). 


\section{Cel pracy}

Celem ogólnym pracy była ocena efektywności terapii Temsirolimusem myszy z ortotopowym jasnokomórkowym rakiem nerki. Wyniki badań stanowić będą podstawę w opracowaniu optymalnego czasu podania Temsirolimusu celem zahamowania rozwoju choroby i wydłużenia czasu przeżycia.

Cele szczegółowe obejmowały:

1. Ocenę potencjału terapeutycznego Temsirolimusu w zaawansowanej postaci RCC u myszy Balb/c.

2. Wykluczenie niekorzystnego wpływu immunosupresyjnego Temsirolimusu na odpowiedź układu immunologicznego, skierowaną przeciw RCC we wczesnym stadium choroby.

3. Wpływ terapii Temsirolimusem na wydłużenie czasu przeżycia i zahamowanie progresji nowotworu myszy z na RCC.

\section{Materiały i metody}

Wykorzystane $\mathrm{w}$ doświadczeniach linie komórkowe utrzymywane były w warunkach standardowych, tj. w temperaturze $37^{\circ} \mathrm{C}, \mathrm{w}$ atmosferze wzbogaconej 5\% CO2 i nasyconej parą wodną. Wyjściowe medium hodowlane stanowiła pożywka Dulbecco’s Modified Eagle’s Medium (DMEM) z dodatkiem 10\% płodowej surowicy bydlęcej (FBS) i antybiotyku gentamycyny o stężeniu końcowym $50 \mu \mathrm{g} / \mathrm{ml}$ (Gibco Invitrogen, Carlsbad, CA). Komórki linii adherentnych po osiągnięciu 90\% konfluencji pasażowano (średnio co $3-4$ dni). Pasażu dokonywano w obecności 1x stężonej trypsyny (Gibco Invitrogen, Carlsbad, CA), po uprzednim zebraniu medium i odpłukaniu pozostałości pożywki roztworem PBS (Gibco Invitrogen, Carlsbad, CA).

W doświadczeniu wykorzystano komórki RenCa, tj. linię komórek mysiego raka nerki wyizolowaną od samic myszy szczepu typu BALB/c. Linia komórkowa mysiego raka nerki była podstawą do otrzymania modyfikowanej genetycznie linii komórkowej RenCaLuc. Linię komórkową RenCaLuc uzyskano poprzez transdukcję linii komórkowej RenCa wektorem lentiwirusowym kodującym cDNA reporterowego genu lucyferazy. Wektor otrzymano dzięki uprzejmości dr n. med. Urszuli Kazimierczak z Katedry Biotechnologii Medycznej Uniwersytetu Medycznego w Poznaniu. Transdukcję przeprowadzono z wykorzystaniem zestawu do trandukcji Calcium Phosphate Kit (Invitrogen, Carlsbad, CA) zgodnie z protokołem dostarczonym przez producenta.

W doświadczeniu wykorzystano samice myszy szczepu BALB/c. Zwierzęta należały do pokolenia F1 i były w wieku 8 do 12 tygodni. Zwierzęta BALB/c zakupiono w Centrum Medycyny Doświadczalnej i Klinicznej Polskiej Akademii Nauk w Warszawie. Doświadczenia zostały przeprowadzone zgodnie z wytycznymi i za zgodą Lokalnej Komisji Etycznej ds. Doświadczeń na Zwierzętach Uniwersytetu Rolniczego im. A. Cieszkowskiego w Poznaniu.

Kontroli ekspresji transgenu in vitro dokonano z wykorzystaniem zestawu Luciferase Assay Kit (Sigma, Saint Louis, MI). Identyfikacja genu reporterowego polegała na zarejestrowaniu przez luminometr emisji fotonów promieniowania świetlnego, po uprzednim podaniu substratu dla lucyferazy (CoA, ATP, lucyferyna) (Sigma, Saint Louis, MI, USA).

Dokonano donerkowej implantacji komórek RenCaLuc. Przed procedurą zwierzęta usypiano preparatem Avertin. Myszom zaaplikowano dootrzewnowo roztwór Avertin (2-2-2 tribromoetanol rozpuszczony w alkoholu tetramylowym) w dawce $0,7 \mathrm{mg} / \mathrm{kg}$ masy ciała. Następnie przeprowadzono mechaniczną epilację lewej okolicy lędźwiowej. Za pomocą strzykawki tuberkulinowej wprowadzono w okolicę podtorebkową 5X104 komórek RenCaLuc zawieszonych w $10 \mu \mathrm{l}$ PBS. Ranę pooperacyjną zaopatrzono 2 - 3 szwami podskórnymi i skórnymi.

Celem przygotowania zwierząt do obrazowania in vivo dokonano dootrzewnowej iniekcji lucyferyny. Procedurę poprzedziło sporządzenie wyjściowego roztworu o stężeniu $15 \mathrm{mg} / \mathrm{ml}$ poprzez rozpuszczenie lucyferyny w buforze DBPS (Caliper Life Sciences, Hopkinton, MA). Otrzymany roztwór przefiltrowano przez filtr o średnicy $0,22 \mu \mathrm{m}$. Iniekcji dokonywano w lewy dolny kwadrant jamy brzusznej. Dla uzyskania pożądanego stężenia w ustroju (150 mg lucyferyny/kg masy ciała) ilość podawanego roztworu wynosiła 10 $\mu \mathrm{l} / \mathrm{g}$ masy ciała. Dystrybucja preparatu w organizmie myszy trwała od 5 do 15 minut.

Lucyferyna jest związkiem chemicznym zbudowanym z pierścienia benzotiazolowego połączonego $\mathrm{z}$ pierścieniem karboksytiazolowym. Występuje w organizmach żywych naturalnie (Lampyridae), 
charakteryzuje się niską antygenowością, niską toksycznością i niską masą cząsteczkową, zatem swobodnie pokonuje barierę błony komórkowej. W obecności CoA, ATP i enzymu lucyferazy ulega reakcji oksydacji, powodując emisję fotonów promieniowania świetlnego o barwie zielononiebieskiej.

Wizualizacji komórek RenCaLuc in vivo dokonano w urządzeniu IVIS Imaging System (Caliper Life Sciences, Hopkinton, MA), przyżyciowo. Dokonywano dwóch pomiarów: jednego w projekcji brzusznej, drugiego w grzbietowej. Pomiar opierał się na rejestracji emisji fotonów promieniowania świetlnego. Wykonano 102 zdjęcia, na podstawie których przeprowadzono ocenę zaawansowania choroby. Po przeprowadzeniu badania, myszy wybudzano oraz umieszczano w warunkach hodowlanych.

Temsirolimus (Wyeth Pharmaceuticals, Philadelphia, PA) podawano wyselekcjonowanym zgodnie z planem przebiegu eksperymentu grupom myszy, co siedem dni, w dawce 10mg/kg masy ciała. Iniekcji dokonywano drogą dootrzewnową przy użyciu strzykawki tuberkulinowej, po uprzednim wziewnym podaniu anestetyku (2,5-3,5\% izofluran). Celem oceny potencjału terapeutycznego Temsirolimusu zwierzęta losowo podzielono na 3 grupy eksperymentalne. Pierwszą grupę badaną stanowiły zwierzęta poddawane terapii Temsirolimusem 24 godziny po implantacji komórek nowotworowych (grupa „CCI9”). Drugą grupę stanowiły myszy przyjmujące lek od chwili zidentyfikowania przerzutu ogniska nowotworowego w płucu (grupa „CCI9met”). Kwalifikacji zwierząt manifestujących przerzuty w płucu dokonano w oparciu o system klasyfikacji TNM. Zwierzęta przyjmujące Temsirolimus od momentu zakwalifikowania do stadium IV zaawansowania RCC (przerzut w płucu) zostały wyodrębnione z grupy odniesienia. Grupę odniesienia stanowiły samice szczepu BALB/c nie poddane terapii, przyjmujące placebo w postaci $10 \mu \mathrm{l}$ roztworu PBS (grupa „bez leczenia”) (ryc. 1).

Oceny dokonywano przez blisko 8 tygodni trwania eksperymentu zgodnie z w/w metodyką.

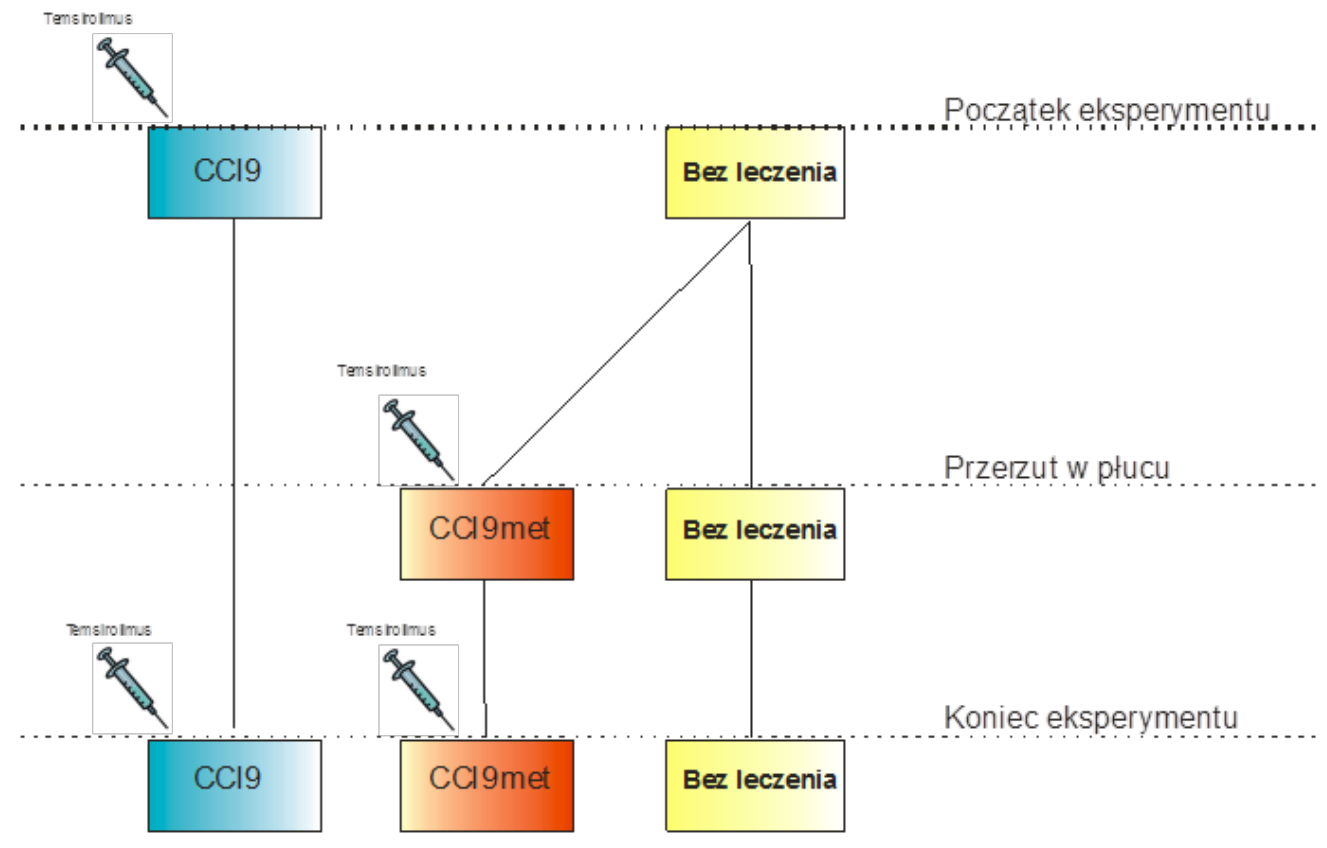

Rycina 1. Schematyczne przedstawienie zasady wyodrębniania grup badanych [Źródło: opracowanie własne]

\section{Wyniki}

Identyfikacji produktu genu reporterowego luc in vitro dokonano poprzez pomiar poziomu ekspresji lucyferyny w lizacie komórek RenCaLuc z wykorzystaniem luminometru. W próbie badanej emisja wynosiła 1740 jednostek/ml.

Identyfikacji ognisk nowotworowych in vivo dokonywano zgodnie z opisaną metodyką poprzez analizę wykonanych zdjęć. U myszy szczepu BALB/c po donerkowej implantacji komórek RenCaLuc, emisja fotonów ograniczała się do ognisk występowania pierwotnego bądź przerzutującego RCC. Obrazy wykonywano w projekcji brzusznej i grzbietowej dla każdej badanej grupy (ryc. 2). 

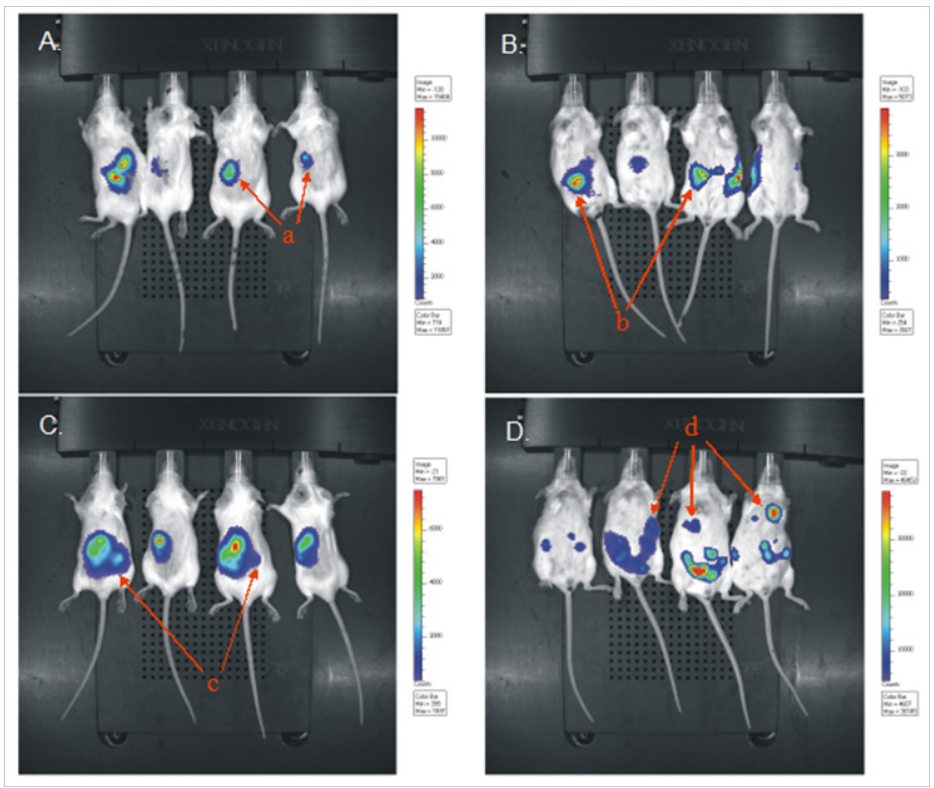

Rycina 2. Przedstawiono 4 reprezentatywne myszy z grupy „CCI9” (A) w 10 dniu eksperymentu: ogniska nowotworowe ograniczone do nerek i prawdopodobnie powięzi Gerota (a); (B) 4 myszy w 10 dniu eksperymentu z grupy „bez leczenia"- ogniska nowotworowe widoczne w obrębie nerek, prawdopodobnie powięzi Gerota i okolicznych węzłów chłonnych; (C) 4 myszy z grupy „CCI9” w 32 dniu eksperymentu- ogniska nowotworowe zajmujące nerkę, powięź Gerota, okoliczne węzły chłonne i otrzewną(c); (D) 4 myszy z grupy „CCI9met” w 32 dniu eksperymentu z zaznaczonymi guzami w obrębie płuc

Malejąca liczebność zwierząt stała się podstawą do przeprowadzenia analiz czasu przeżycia w poszczególnych grupach. Ilość przerzutów i obserwacja remisji choroby była podstawą do oceny efektu terapeutycznego Temsirolimusu w poszczególnych grupach. Ocena zaawansowania choroby umożliwiła statystyczną analizę OS (Overal Survival), PFS (Progression Free Survival), TTP (Time To Progression).

Wyniki doświadczenia wskazują na wydłużenie średniego czasu przeżycia (OS) zwierząt w grupie przyjmującej lek od momentu zidentyfikowania przerzutu ogniska nowotworowego w płucu zwierzęcia („CCI9met”) o około 7 dni w stosunku do dwóch pozostałych grup doświadczalnych: poddanej terapii Temsirolimusem 24 godziny po implantacji komórek nowotworowych („CCI9”) oraz myszy grupy kontrolnej („bez leczenia”). Dane przedstawione zostały na ryc. 3 .

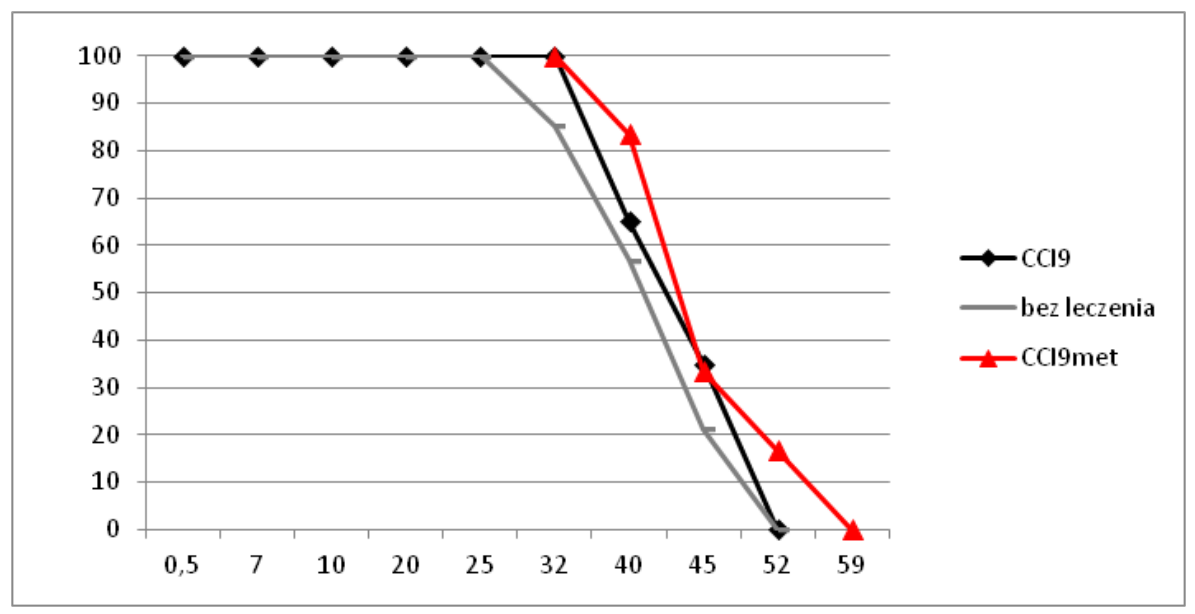

Rycina 3. Przeżywalność myszy poddanych leczeniu Temsirolimusem 24 godziny po implantacji komórek nowotworowych (CCI9), myszy poddanych leczeniu od momentu zidentyfikowania przerzutu w płucu (CCI9met) i grupy kontrolnej 
Dokonano analizy czasu do progresji choroby (TTP). Grupy eksperymentalne stanowiła grupa otrzymująca leczenie od początku implantacji komórek RenCa w okolicę podtorebkową nerki („CCI9”) oraz grupa kontrolna („bez leczenia”). Nie wykazano różnic w długości czasu do progresji nowotworu (taki sam TTP w obydwu grupach). 20 dnia badania ogniska nowotworowe w płucach można było zaobserwować w obydwu grupach badanych myszy. 45 dnia badania przerzuty nowotworowe w płucach obserwowano u 100\% zwierząt obydwu grup. Dane zostały przedstawione na ryc. 4.

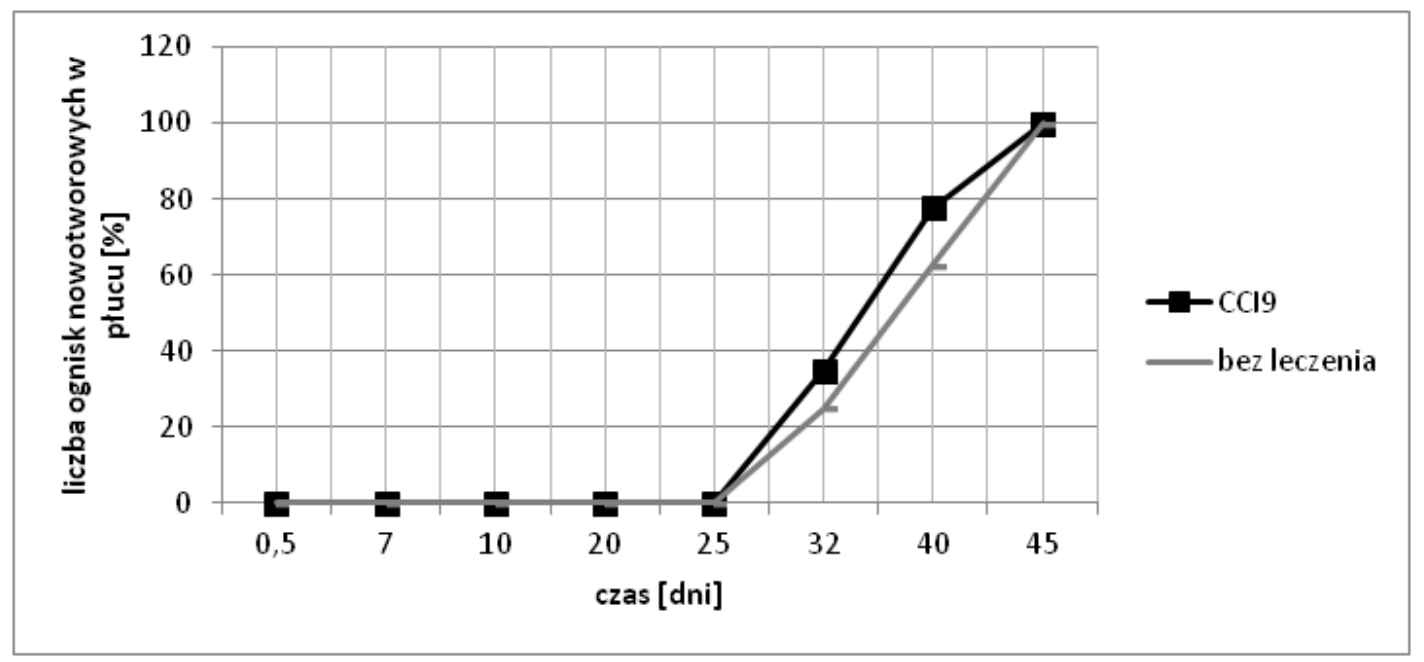

Rycina 4. Wykres przedstawiający liczbę zwierząt laboratoryjnych mających przerzuty w płucu w grupie zwierząt leczonych CCI9 od początku eksperymentu w stosunku do grupy kontrolnej, nie poddanej terapii

Pomiaru czasu wolnego od progresji choroby dokonywano poprzez ocenę średniego czasu wolnego od progresji (PFS) choroby u badanych zwierząt. W doświadczeniu analizowano PFS zwierząt przyjmujących Temsirolimus od momentu zidentyfikowania przerzutu w płucu („CCI9met”) w porównaniu do grupy kontrolnej („,bez leczenia”). Ocena progresji choroby była utrudniona, gdyż wymagałaby wykonywania autopsji w odstępach kilkudniowych, co zwiększyłoby liczbę zwierząt laboratoryjnych koniecznych do przeprowadzenia eksperymentu jak i koszt eksperymentu. Jako kryterium czasu wolnego od progresji przyjęto zatem czas, w którym przeżywalność zwierząt utrzymywała się na stałym poziomie. Liczebność grupy poddanej terapii od momentu zidentyfikowania przerzutu w płucu („CCI9met”) spadła ze 100\% i utrzymywała się na poziomie 90\% od 25 do 32 dnia trwania eksperymentu, podczas gdy przeżywalność w grupie kontrolnej („bez leczenia”) spadła w tym odstępie czasu o blisko 40\% (ze 100 do 65\%). Stwierdzono wydłużenie czasu wolnego od progresji choroby w grupie poddanej terapii Temsirolimusem od momentu zlokalizowania przerzutu w płucu („CCI9met”) o około 8 dni. Dane przedstawiono na ryc. 3.

\section{Dyskusja}

Rak jasnokomórkowy nerki należy do nowotworów immunogennych, a przebieg choroby jest ściśle uzależniony od reaktywności układu immunologicznego. Na RCC statystycznie częściej zapadają chorzy z wtórnymi i pierwotnymi niedoborami odporności. W pobranym podczas zabiegów chirurgicznych lub biopsji materiale biologicznym stwierdza się obecność odczynu zapalnego oraz liczne nacieki limfocytarne [1]. Ze względu na opisaną reaktywność układu immunologicznego, terapia RCC przez wiele lat oparta była na próbach jego stymulacji przez ogólnoustrojowe podawanie interferonu- $\alpha$ (IFN- $\alpha$ ) i interleukiny 2 (IL-2) [16, 26]. Izolowane lub skojarzone leczenie wymienionymi cytokinami znajduje powszechne zastosowanie jako terapia pierwszego rzutu u chorych z RCC we wczesnym stadium rozwoju. Mimo niezadowalających wyników w leczeniu zaawansowanego raka nerki [9], do 2005 roku immunoterapia oparta na podawaniu wysokiej dawki IL-2 stanowiła jedyny schemat leczenia wykazujący jakiekolwiek efekty kliniczne [17]. Późniejszy rozwój terapii celowanych doprowadził do zmiany strategii terapeutycznych u chorych w zaawansowanym stadium jasnokomórkowego raka nerki. 
Poznanie centralnej roli szlaku sygnałowego PI3K/Akt/mTOR w patogenezie nowotworzenia doprowadziło do opracowania leków specyficznie celujących w poszczególne etapy aktywacji szlaku PI3K/Akt/mTOR $[7,17]$. W przedstawionych badaniach podjęto próbę oceny potencjału terapeutycznego i wykluczenia immunosupresyjnego wpływu Temsirolimusu u myszy cierpiących na RCC. Badania przeprowadzono w tzw. modelu terapeutycznym, w którym myszy po pierwotnej implantacji komórek nowotworowych poddawano terapii preparatem zgodnie z wybranym schematem. Oceniano wpływ terapii na wydłużenie czasu przeżycia całkowitego, czasu do progresji choroby oraz czasu wolnego od progresji u zwierząt z RCC. Ocenę działania Temsirolimusu prowadzono w modelu mysim ortotopowego raka nerki.

Temsirolimus, zarówno w swojej zestryfikowanej jak i niezestryfikowanej postaci (Sirolimus), wykazuje hamujący wpływ na sygnalizację szlaku PI3K/Akt/mTOR [18, 19]. Temsirolimus wiążąc się z białkiem FKBP12 (wewnątrzkomórkowa izomeraza prolinowa) formuje kompleks znoszący aktywność mTOR mobilizującego komórki do proliferacji, neoangiogenezy i aktywacji cyklu komórkowego.

Celem pierwszorzędowym (primary end point) przeprowadzonych badań była ocena czasu przeżycia całkowitego zwierząt. Wydłużenie średniego przeżycia całkowitego wynosiło ok. 7 dni. 52 dnia trwania eksperymentu przeżywalność zwierząt z grupy „CCI9met” wynosiła 15\% w porównaniu do o\% w grupie „bez leczenia”. Nie stwierdzono natomiast wydłużenia średniego czasu przeżycia całkowitego pomiędzy zwierzętami grupy poddanej terapii Temsirolimusem od początku doświadczenia („CCI9”) i grupy kontrolnej („bez leczenia”) (ryc. 3). Rozbieżność ta może wynikać z immunosupresyjnego wpływu Temsirolimusu na układ odpornościowy i częściowego maskowania immunogenności RCC we wczesnej fazie rozwoju choroby. W ustroju, zarówno niemetabolizowany Temsirolimus, jak i jego główny metabolit Rapamycyna wykazują działanie biologiczne [20]. Rapamycyna została po raz pierwszy zidentyfikowana jako lek przeciwgrzybiczny $[21,22]$. Identyfikacja właściwości immunosupresyjnych Rapamycyny [23] umożliwiła wykorzystanie leku w procedurach allogenicznych transplantacji nerki [24]. Immunosupresyjny wpływ Rapamycyny na układ immunologiczny polega na zmniejszeniu odpowiedzi limfocytów $\mathrm{T}$ na sygnały proproliferacyjne, indukowanej przez IL-1, Il-2, IL-3, IL-4, IL-6. Preparat wykorzystywano w zabiegach implantacji stentgraftów u chorych z miażdżycą naczyń wieńcowych. Pokryte Rapamycyną stentgrafty ograniczały proliferację komórek mięśni gładkich indukowaną przez lokalny proces zapalny [25]. Niemniej, w literaturze brak doniesień na temat immunosupresyjnego działania Temsirolimusu, jak i dowodów wykluczających hamujący wpływ na układ immunologiczny. Nie zostało wyjaśnione dlaczego analogi Rapamycyny (Temsirolimus) uznawane są za preparaty pozbawione właściwości immunosupresyjnych, podczas gdy jednym z głównych efektów biologicznych Rapamycyny jest hamujący wpływ na układ odpornościowy. Nawet niewielka supresja układu immunologicznego może w całości zahamować przeciwnowotworową odpowiedź układu odpornościowego. Właściwość tę wykazano w badaniach z wykorzystaniem Captoprilu - inhibitora konwertazy angiotensyny, który jest powszechnie stosowany w leczeniu nadciśnienia. Pomimo swoich właściwości przeciwnowotworowych w badaniach przedklinicznych wykazano wpływ Captoprilu na promocję wzrostu guzów immunogennych (takich jak RCC) poprzez osłabienie przeciwnowotworowej odpowiedzi układu immunologicznego, mimo braku ogólnoustrojowych efektów immunosupresji [7, 27].

W kolejnych doświadczeniach oceniano czas wolny od progresji choroby. Wyniki III fazy badań klinicznych FDA wykazały wydłużenie czasu wolnego od progresji choroby w grupie chorych z zaawansowanym stadium RCC przyjmującej Temsirolimus w stosunku do grupy placebo o 5,5 miesiąca [16]. W związku z utrudnioną oceną masy guza w płucu, jako pośrednie kryterium zahamowania progresji nowotworu wybrano czas, w którym przeżywalność zwierząt laboratoryjnych w danej grupie utrzymywała się na stałym poziomie. Przeżywalność grupy poddanej terapii od momentu zidentyfikowania przerzutu w płucu („CCI9met”) spadła o 10\% od 25 do 32 dnia trwania eksperymentu, podczas gdy przeżywalność w grupie kontrolnej („bez leczenia”) spadła w tym odstępie czasu ze 100 do 65\%. Dane przedstawione na ryc. 7 wskazują na wydłużenie czasu wolnego od progresji choroby w grupie poddawanej terapii od momentu zdiagnozowania przerzutu w płucu („CCI9met”) w stosunku do grupy kontrolnej („bez leczenia”) o 8 dni. Kolejny krokiem była próba oceny czasu do progresji choroby. Myszy, zarówno z grupy poddanej terapii Temsirolimusem od początku rozwoju nowotworu („CCI9”), jak i grupy nie poddanej żadnej terapii („bez leczenia”) pierwsze ogniska nowotworowe manifestowały 25 dnia trwania eksperymentu. Niemniej w 32 dniu prowadzonych doświadczeń 35\% zwierząt grupy „CCI9” posiadała ogniska nowotworowe w tym narządzie w porównaniu do $20 \%$ zwierząt grupy „bez leczenia”. W 40 dniu badania dysproporcja liczby ognisk nowotworowych 
w w/w grupach wzrosła i wynosiła odpowiednio 75 do 58\%. Przeprowadzona ocena TTP pomiędzy grupami nie wykluczyła immunosupresyjnego wpływu Temsirolimusu (ryc. 4). Wyższy odsetek myszy z ogniskami nowotworowymi w płucu w grupie przyjmującej preparat w stosunku do grupy kontrolnej może świadczyć o zahamowaniu odpowiedzi układu odpornościowego przez Temsirolimus. Wymykanie się RCC spod nadzoru immunologicznego może być związane z ograniczeniem przez Temsirolimus odpowiedzi limfocytów T na sygnalizację IL-1, Il-2, IL-3, IL-4, IL-6 [25]. Dane przedstawono na ryc. 4.

Celem badań przeprowadzonych przez Bhatia i wsp. było wykluczenie potencjalnie immunosupresyjnego wpływu Temsirolimusu i rozważenie ewentualnej możliwości kompensacji immunosupresji przez równoczesną stymulacjęukładu odpornościowego. Rozważaniajednak dostarczyły dodatkowych wątpliwości. III faza badań klinicznych, która miała na celu porównać monoterapię Temsirolimusem, IFN- $\alpha$ (silny wpływ immunostymulujący) i połączoną terapię obydwoma preparatami dostarczyła niejednoznacznych wyników. Wydłużenie czasu przeżycia całkowitego w przypadku monoterapii Temsirolimusem wynosiło 10,9 miesiąca w porównaniu do 7,3 miesięcy wydłużenia czasu przeżycia w grupie leczonej INF- $\alpha$. Natomiast kombinacja obu terapii wydłużyła OS o 8,4 miesiąca, dając wartość pośrednią pomiędzy obydwiema monoterapiami [16]. Uzyskany wynik może wynikać nie tylko z niższej dawki Temsirolimusu użytej w doświadczeniu, ale również z przeciwstawnych efektów wywieranych przez badane preparaty na układ immunologiczny [7].

Biorąc pod uwagę brak obserwowanych efektów klinicznych w połączonej terapii Temsirolimusem i środkami immunostymulujacymi [Bhatia i wsp., 2009], jest prawdopodobne że podobne podejścia badawcze zostaną zarzucone [Wysocki, 2009]. Brak powszechnie stosowanych biomarkerów pozwalających ocenić wydajność hamowania mTOR przez Temsirolimus nie pozwala wykluczyć innych szlaków mogących włączać sygnalizacje przez mTOR Ponadto zidentyfikowano alternatywne szlaki (RAS/RAF/MEK/ERK) mogące uruchamiać mechanizmy charakterystyczne dla mTOR, nawet po jego inaktywacji. [10]. Wskazuje to na możliwość i być może konieczność celowania w inne niż mTOR komponenty komórkowe promujące geny sprzyjające procesowi nowotworzenia. Aktualnie trwają próby kliniczne mające na celu ocenę efektywności kombinacyjnych terapii Temsirolimusem lub Everolimusem w skojarzeniu z Sunitinibem, Sorafenibem, Imatinibem, Vatalanibem czy Bevacizumabem. W najbliższej przyszłości spodziewane jest zidentyfikowanie biomarkerów, czynników prognostycznych jak i zmodyfikowanych kryteriów oceny wydajności leczenia u chorych poddanych terapii celowanej w mTOR [7].

\section{Konflikt interesu / Conflict of interest}

Nie występuje / None

\section{Etyka/Ethics}

Treści przedstawione w artykule są zgodne z zasadami Deklaracji Helsińskiej, dyrektywami EU oraz ujednoliconymi wymaganiami dla czasopism biomedycznych.

\section{Piśmiennictwo / References}

[1] Suchorska WM. Badania przedkliniczne modyfikowanej genem Hyper-IL-11 terapeutycznej szczepionki nowotworowej w jasnokomórkowym raku nerki. Rozprawa doktorska.oai:www.wbc.poznan.pl:106370 (2008).

[2] Lam JS, Klatte T, Kimb HJ, Patard JJ, Breda A, Zisman A, Pantuck AJ, Figlin RA. Prognostic factors and selection for clinical studies of patients with kidney cancer. Crit. Rev. Oncol./Hematol. (2008) 65(3): 235-262.

[3] Wojciechowska U, Didkowska J. Zachorowania i zgony na nowotwory złośliwe w Polsce. Krajowy Rejestr Nowotworów, Centrum Onkologii - Instytut im. Marii Skłodowskiej - Curie. Dostępne na stronie http:// onkologia.org.pl/raporty/ dostęp z dnia 14.03.2017

[4] Brugalolas J. Renal-Cell Carcinoma - Molecular Pathways and Therapies. N Engl J Med (2007) 356:185187 
[5] Yang X, Yang C, Farberman A, Rideout TC, de Lange CF, France J, Fan MZ. The mammalian target of rapamycin-signaling pathway in regulating metabolism and growth. J Anim Sci. (2008) Apr;86(14 Suppl):E36-50.

[6] Dancey JE. Therapeutic targets: mTOR and related pathways. Cancer Biol Ther. (2006) 5:1065-1073.

[7] Wysocki PJ. mTOR in renal cell cancer: modulator of tumor biology and therapeutic target.» Expert review of molecular diagnostics (2009) 9.3: 231-241.

[8] Shor B, Zhang WG, Toral-Barza L, Lucas J, Abraham RT, Gibbons JJ, Yu K. A new pharmacologic action of CCI-779 involves FKBP12-independent inhibition of mTOR kinase activity and profound repression of global protein synthesis. Cancer research, (2008) 68(8), 2934-2943.

[9] Bhatia N, Zhao J, Wolf DM, Agarwal R. Inhibition of human carcinoma cell growth and DNA synthesis by silibinin, an active constituent of milk thistle: comparison with silymarin. Cancer Lett (1999) 147: 77-84.

[10] Cho H, Ahn D-R, Park H, Yang EG. Modulation of p30o binding by posttranslational modifications of the C-terminal activation domain of hypoxia-inducible factor-1a. FEBS Lett. 2007;581:1542-1548.

[11] Pantuck AJ, Zeng G, Belldegrun AS, Figlin RA. Pathology, Prognosis, and Targeted Teraphy for Renal Cell Carcinoma: Exploiting the Hypoxia-Induced Pathway. Clin. Cancer Res. . Cancer Res. (2003) 9: 4641-52.

[12] Thomas GV, Tran C, Mellinghoff IK, Welsbie DS, Chan E, Fueger B et al. Hypoxia-inducible factor determines sensitivity to inhibitors of mTOR in kidney cancer. Nat Med (2006). 12: 122-127.

[13] Del Bufalo D, Ciuffreda L, Trisciuoglio D, Desideri M, Cognetti F,2 Zupi G, Milella M. Antiangiogenic Potential of the Mammalian Target of Rapamycin Inhibitor Temsirolimus. Cancer Res 2006;66:55495554 .

[14] Hu Y, Liu J, Huang H. Recent agents targeting HIF-1a for cancer therapy. J Cell Biochem (2013) 114:498509

[15] Wimmer CD, Rentsch M, Crispin A, Illner WD, Arbogast H, Graeb C, Jauch KW, Guba M. The janus face of immunosuppression - de novo malignancy after renal transplantation: the experience of the Transplantation Center Munich. Kidney Int. 2007 Jun;71(12):1271-8

[16] Hudes G, Carducci M, Tomczak P, Dutcher J, Figlin R, Kapoor A, Staroslawska E, Sosman J, McDermott D, Bodrogi I, et al. Global ARCC Trial. Temsirolimus, interferon alfa, or both for advanced renal cell carcinoma. N. Engl. J. Med. (2007) 356:2271-2281.

[17] Brugarolas J. Predictive Biomarkers for Molecularly Targeted Therapies in Renal Cell Carcinoma.J Natl Compr Canc Netw. 2016 Jul;14(7):925-7

[18] Shor B, Zhang WG, Toral-Barza L, Lucas J, Abraham RT, Gibbons JJ, Yu K. A new pharmacologic action of CCI-779 involves FKBP12-independent inhibition of mTOR kinase activity and profound repression of global protein synthesis. Cancer Res. 2008 Apr 15;68(8):2934-43. doi: 10.1158/00o8-5472.CAN-076487.

[19] Tzatsos A, Kandror KV. Nutrients suppress phosphatidylinositol 3-kinase/Akt signaling via raptordependent mTOR-mediated insulin receptor substrate 1 phosphorylation. Mol Cell Biol. 2006 Jan;26(1):63-76.

[20] Leone M, Crowell KJ, Chen J, Jung D, Chiang GG, Sareth S, Abraham RT, Pellecchia M. The FRB domain of mTOR: NMR solution structure and inhibitor design. Biochemistry. 2006 Aug 29;45(34):10294-302.

[21] Sehgal SN, Baker H, Vézina C. Rapamycin (AY-22,989), a new antifungal antibiotic. II. Fermentation, isolation and characterization. J Antibiot (Tokyo). (1975) 28(10):727-32.

[22] Sehgal SN. Sirolimus: its discovery, biological properties, and mechanism of action. Transplant Proc. (2003) 35(3 Suppl):7S-14S.

[23] Sehgal SN, Molnar-Kimber K, Ocain TD, Weichman BM. Rapamycin: a novel immunosuppressive macrolide. Med Res Rev. (1994)14(1):1-22

[24] Granger DK, Cromwell JW, Chen SC, Goswitz JJ, Morrow DT, Beierle FA, Sehgal SN, Canafax DM, Matas AJ. Prolongation of renal allograft survival in a large animal model by oral rapamycin monotherapy. Transplantation. (1995) 27;59(2):183-6.

[25] Sousa JE, Costa MA, Abizaid A, Feres F, Seixas AC, Tanajura LF, Mattos LA, Falotico R, Jaeger J, Popma JJ, Serruys PW, Sousa AG. Four-year angiographic and intravascular ultrasound follow-up of patients 
treated with sirolimus-eluting stents. Circulation. 2005 10;111(18):2326-9.

[26] Milecki P. Ocena najnowszych trendów leczenia nowotworów układu moczowego prezentowanych na Konferencji ASTRO 2015, San Antonio, USA. Zeszyty Naukowe WCO (2016) vol 13. No 4, 79-82

[27] Wysocki PJ, Kwiatkowska EP, Kazimierczak U, Suchorska W, Kowalczyk DW, Mackiewicz A. Captopril, an angiotensin-converting enzyme inhibitor, promotes growth of immunogenic tumors in mice. Clin Cancer Res. 2006 Jul 1;12(13):4095-102. 